\title{
On the structure, ecology and distribution of the species of Mitrula s.lat. (Ascomycetes, Geoglossaceae)
}

\author{
Esteri Kankainen \\ The Subarctic Research Station of the University of Turku, Turku. Finland
}

Introduction

The matter under consideration is a part of my research including the larger fungi in arctic and subarctic regions. For eight years I have also collected Mitrula material, and some notes are published in Kallio \& KankaINEN (1964, 1966). I have had the opportunity to participate on the excursions of Kevo, the Subarctic Research Station of the University of Turku under the leadership of Prof. Paavo Kallio. Our Mitruta collections from these trips to Spitsbergen in 1966 and northeastern Canada in 1967 are taken into consideration in the present paper. The specimens studied are preserved in the following herbariums:

$\mathrm{H} \quad$ Botanical Museum of the University of Helsinki

HFR Finnish Forest Research Institute, Helsinki

HPP Department of Phytopathology, University of Helsinki

KEVO Collections of the Subarctic Research Station of the University of Turku, Utsjoki

OULU Botanical Museum of the University of Oulu

S Botanical Museum of Stockholm

TROMS Department of Botany, Tromsø Museum

TUR Botanical Museum of the University of Turku

Only unpublished finds are included in the enclosed lists of the studied specimens, but the notes of Kallio \& Kankainen (1964, 1966) are also plotted on the maps (Figs. 1, 3).

I express my best thanks for direction and advice of great value to my teacher Prof. Paavo Kallio, for valuable notes and discussion to Phil. lic. Tauno Ulvinen, for determination of the mosses in question to Phil. mag. Unto Laine, and for the linguistic revision to Mrs. Linna Müller-Wille. I have received financial support from Suomen Kulttuurirahasto.

Mitrula Fr., Syst. Myc. 1, p. 491. 1821. (sensu strict.)

Imai (1941) and Maas Geesteranus (1964) have unravelled the history of the genus Mitrula, and we only ascertain the large variation in its content from one extreme to the other, from the wide opinion of Karsten (1871) and Massee (1897) to the narrow one of ImaI $(1941,1956)$ and MAAS Geesteranus (1964). Imai (1956), divided Geoglossaceae into new subfamilies and tribes. Consequently the tribe Mitruleae includes only one monotypic genus Mitrula on the basis of that the ascocarp of $M$. paludosa is hemiangiocarpic. In the tribe Gymnomitruleae is included one genus Gymnomitrula with two species $G$. abietis and $G$. gracilis on the basis of that the ascocarp of $M$. pusilla is gymnocarpic. According to MAAs GeesteRaNus (1964) the genus Mitrula is also monotypic. He has renewed the old genus Heyderia which is in his opinion monotypic, because the place of $M$. gracilis is indistinct. 
In the present paper we have taken the genus Mitrula in a larger sense than the last two authors, but sensu stricto compared with the opinion of e.g. Fries (1821), NANNFELDT (1942) and EGkblad (1963).

1. Mitrula paludosa Fr., Syst. Myc. 1, p. 491. 1821.

Helvella laricina Vill., Fl. Dauph. 3, p. 1045, Tab. 56. 1786-1789.

Clavaria phalloides Bull., Champ. France, p.

214, Tab. 463, Fig. 3. 1791-1798.

Clavaria epiphylla Dicks., Plant. Crypt. 3, p. 22,

Tab. 9, Fig. 10. 1793.

Leotia ludwigii, dicksoni, bulliardi Pers., Syn.

Fung., pp. 611, 612, Tab. 3, Fig. 13. 1801.

Leotia laricina Pers., Syn. Fung., p. 614. 1801.

Helvella aurantiaca Cumino, Act. Acad. Sci.

Tour., p. 221. 1805.

Mitrula aurantia Cumino, Fung. Vall. Pisii in

Act. Tur. 1806.

Leotia uliginosa Pers., Myc. Eur. 1, p. 200. 1822.

Leotia uliginosa var. aurantiaca Pers., Ibid., p. 201. 1822

Mitrula phalloides Chev., Fl. Paris, p. 114, Fig.

185. $1826-1827$.

Leotia elegans Berk., London Journ. Bot. 5, p. 6. 1846.

Mitrula elegans Fr., Nov. Symb. Myc., p. 103. 1851.

Mitrula paludosa var. pachyceps Karst., Hedw.

22, p. 17. 1883. - Karst., Acta Soc. F. Fl. Fenn.

2, p. 110.1885 .

Mitrula phalloides var. pachyceps Sacc., Syll.

Fung. 8, p. 33. 1889

Microglossum elegans Underw., Minn. Bot. Stud.

1, p. 495.1896.

Mitrula laricina Mass., Ann. Bot. 11, p. 271. 1897

Mitrula norvegica Rostr., Vid.-Selsk. Skrift. 1: 4, p. 5. 1904

Mitrula phalloides var. aurantiaca Boud., Icon. Myc. 3, Tab. 427. 1909.

External morphology. The size and form of the studied ascocarps of Mitrula paludosa are quite variable. The stipe is $2-5$ centimetres high, smooth, transparent, whitish when fresh, orange yellow when dry. The base of the stem is generally thickened when grown in soft habitat, for instance in mud, forming a large white ball of hyphae. When growing on only a little decayed leaves the base of the stem is not at all thickened or very slightly.

The diameter of the ascigerous portion varies from 0.5 to over one centimetre. Mostly the cap is uneven, folded, but also even, almost spherical caps exist. Sometimes the caps resemble Spathularia. The colour of the cap is yellow - orange yellow when fresh becoming far darker when dried. The form with even, cylindrical-spherical cap is pure yellow in colour (cf. var. cylindrica of VELENOvSKY 1934).

The ascigerous portion is connected to the stem without a sterile margin as seen in Mitrula gracilis and Heyderia abietis. The capstem relation varies very much depending on the habitat. In very rotten, soft places the specimens have thick, short, caespitose stems and small caps (cf. var. pachyceps of KARSTEN 1883); on a more solid substrate the stems grow slender and long, the height of them depending on the depth of the substrate in the water. The caps are generally large and variable in form.

Anatomy. The width of the hyphae in the central part of the stipe widens up to $15 \mu$, in the periphery of the stipe about $6 \mu$. The surface of the stem is smooth.

The size of the asci averages $75-110 \times 5$ - $6 \mu$ (measured in five specimens). The paraphyses are straight, not at all or very slightly enlarged above. The spores are hyaline, not punctate, nonseptate, cylindrical to clavate-cylindrical, in average larger than those in $M$. gracilis. The size of the spores in the following specimens is: Masku 4.6. 1959 $15.3 \times 3.5 \mu$ (50 measurement); Lohja 12 . 6. $196112.2 \times 2.5 \mu$ (50 meas.); Kiiminki 25. 6. $196613.7 \times 2.6 \mu$ (50 meas.); Inari 15. 7. $196811.1 \times 2.6 \mu$ (30 meas.).

The morphological and anatomical features of the specimens studied correspond well with those recorded in the literature (FRIES 1821, Karsten 1871, 1883, Rehm 1896, Massee 1897, Durand 1908, Lloyd 1916, Velenovsky 1934, Imai 1941, Mains 1955, Benedix 1962, Eakblad 1963, Maas Geesteranus 1964). Specimens belonging to var. pachyceps Karst., and possibly to var. sphaerocephala Boud. and var. cylindrica Vel. are included in the list of the studied specimens. Var. castanea Vel. is unknown to us as is f. pallens Eisfelder \& Benedix. Mains (1955, p. 873) has found three types of ascospores occurring in the Mitrula paludosa collections. We have found, however, spores of very variable form and size in the same specimen. The uniseptate spores are very rare in our collections (cf. Massee 1897, Imai 1941, Mains 1955).

Habitat. Mitrula paludosa grows in Finland preferably on decaying leaves of birch, but it is also found on leaves of Alnus, on needles and twigs of Pinus silvestris and Picea 
abies, and among more rotten rests of plants (in mud and slime). Almost without exception the species is found along springs and spring brooks, and in bogs. Often its habitat is a puddle, but always a place where the water changes but does not flow. In such places the oxygen conditions are good. The habitat of our specimen collected in Canada was very similar to those in Lapland.

The habitats of the studied specimens agree with the notes presented in the literature (Fries 1821, Karsten 1871, 1883, Cooke 1871, Rehm 1896, Massee 1897, Durand 1908, Lloyd 1916, Velenovsky 1934, Imai 1941, Nannfeldt 1942, Mains 1955, Benedix 1962). Var. pachyceps of Karsten (1883) is grown «Supra acus Pini sylvestris putrescentes«. It is not yet understood, whether the caespitose form is caused by the quality of the substrate and/or only by the softness of it. BENEDIx (1962, p. 402) presents four «Varietäten« sphaerocephala Boud., pachyceps Karst., castanea Vel. and cylindrica Vel. only as habitat forms.

Phenology. Mitrula paludosa is earlier than $M$. gracilis, occurring from spring to early autumn. The studied unpublished collections are listed in order of occurrance in the following list (abbrev. K). For comparison the other columns are made according to observations of ULvinen (abbrev. U) presented later on, and to collections mentioned by Kallio \& Kankainen 1964 and 1966 (abbrev. $\mathrm{K}$ \& $\mathrm{K}$; all specimens are from Lapland) and Nannfeldt 1942 (abbrev. N).

\begin{tabular}{clrrrr}
\multicolumn{5}{c}{ Number of } & Kpecimens \\
During & May & 1 & U & K \& K & N \\
« June & 49 & 10 & - & 5 \\
« July & 25 & 14 & 2 & 26 \\
« August & 10 & 7 & 13 & 3 \\
« September & 2 & - & - & 2 \\
« October & 1 & - & - & -
\end{tabular}

In Lapland the peak of occurrence of the species is July-August in normal years, in southern Finland June-July.

Most authors record the species to occur in spring and early summer (e.g. Lloyd 1916, Velenovsky 1934, Mains 1955, EGkblad 1963). Benedix (1962) says that in the lowland the species occurs in May-June, in the highland in September.

Distribution. The specimens studied by the writer are mostly from Finland (see Fig. 1). The species has never been found in the alpine regions of Lapland, thus above the Betula tortuosa tree limit. In other parts of Finland it seems to be common. Many collections and observations have been made along the Salpausselkä ridges. The species is common on this area because of the occurrence of springs at the foot of the ridges.

Mitrula paludosa occurs in all of Europe (Sagcardo 1889, Imai 1941, Benedix 1962), in Greenland (LANGe 1957), North America (Durand 1908, Mains 1955), Japan (Imai 1941), that is to say only in the northern hemisphere. EGKBLAD (1963, p. 153) has also noticed that this species does not occur above the tree limit. He says that «In southern Norway it shows a slight tendency to coastal distribution «. Maybe the greater elevation of the inner parts of Norway leads to the aforesaid distribution.

List of the specimens studied (marked with dots on the enclosed map, Fig. 1):

\section{FINLAND}

Al. E ckerö Storby 17.6. 1956 L. E. Kari (TUR); L e m la nd Slätskär 7.6.1946 Uno Vidlund $(\mathrm{H})$.

$A b$. B r o mar v Kärböle 27.6. 1945 Gunnar Marklund (H), Rilax 17.8. 1945 H. Buch (H), Sandö 9.8. 1936 Nicken Malmström $(\mathrm{H})$; K a rja 1 o. h j a Karkali 30.6.1944 L.E. Kari (TUR) and 15. 6. 1962 Timo Koponen $4193(\mathrm{H})$; K u s t a vi in $1863 \mathrm{E}$. Bonsdorff (H), Isokari (Enskär) 26. 6. 1967 Unto Laine (TUR); L o h ja mlk Linnaniemi 27.6. 1944 and 5.7.1944 L. E. Kari (TUR), Vaanila 12.6.1961 Harri T. Toppari (H); M a sk u Kareva 1.6.1943 A. V. Auer (TUR) and 4.6.1959 Paavo Kallio (TUR); Merim a sk u 23.6. 1860 P. A. Karsten (H); Mi e to in en Aarlahti 28. 6.1967 Vesa Oittinen $(\mathrm{H})$; P i ik kiö Harvaluoto 14.6.1967 Vesa Oittinen (H); Pö yt y ä Paju 13 .8. 1962 Paula Siltanen (TUR).

N. E l i m ä k i Mustila 30. 5. 1909 G. G. Tigerstedt $(\mathrm{H})$; Espoo Bodom 4.6.1950 Viljo Kujala 5.21 (HFR); Kirk k o n u m i Bergsta, in 1905 F. W. Klingstedt (H); Perna ja Käldö, July, 1922 W. Nyberg (H) ; P o r n a i n e n Kirveskoski 26. 6. 1916 Tauno Putkonen (HPP); Porv o o 25.6.1860 P. A. Karsten (type material of Mitrula paludosa var. pachyceps Karst.; H) and Oct., 1926 W. Nyberg (H), Vessö 25.6. 1938 W. Nyberg $(\mathrm{H})$; T a m m is a a r i mlk Tvärminne 15 . 6. 1934 Nicken Malmström ( $\mathrm{H})$ and 30.6.1937 E. Häyrén (H); T u u s u la Nummenkylä 16.6. 1946 E.Häyrén $(\mathrm{H})$, Ruotsinkylä 12.7.1941 E. Häyrén (H), 8. 7. 1957 Ann-Marie Malmström (H) and 4.7.1962 Veikko Hintikka (HFR).

St. K a n k a a n pä ä Venesjärvi 5. 6. 1934 Matti Laurila (TUR, HPP) and 16.6.1935 Matti Laurila (HPP); L a i t i l a Leimäki 26. 6. 1949 Holger Såltin (H) Mäentaka 21.7.1955 Holger 


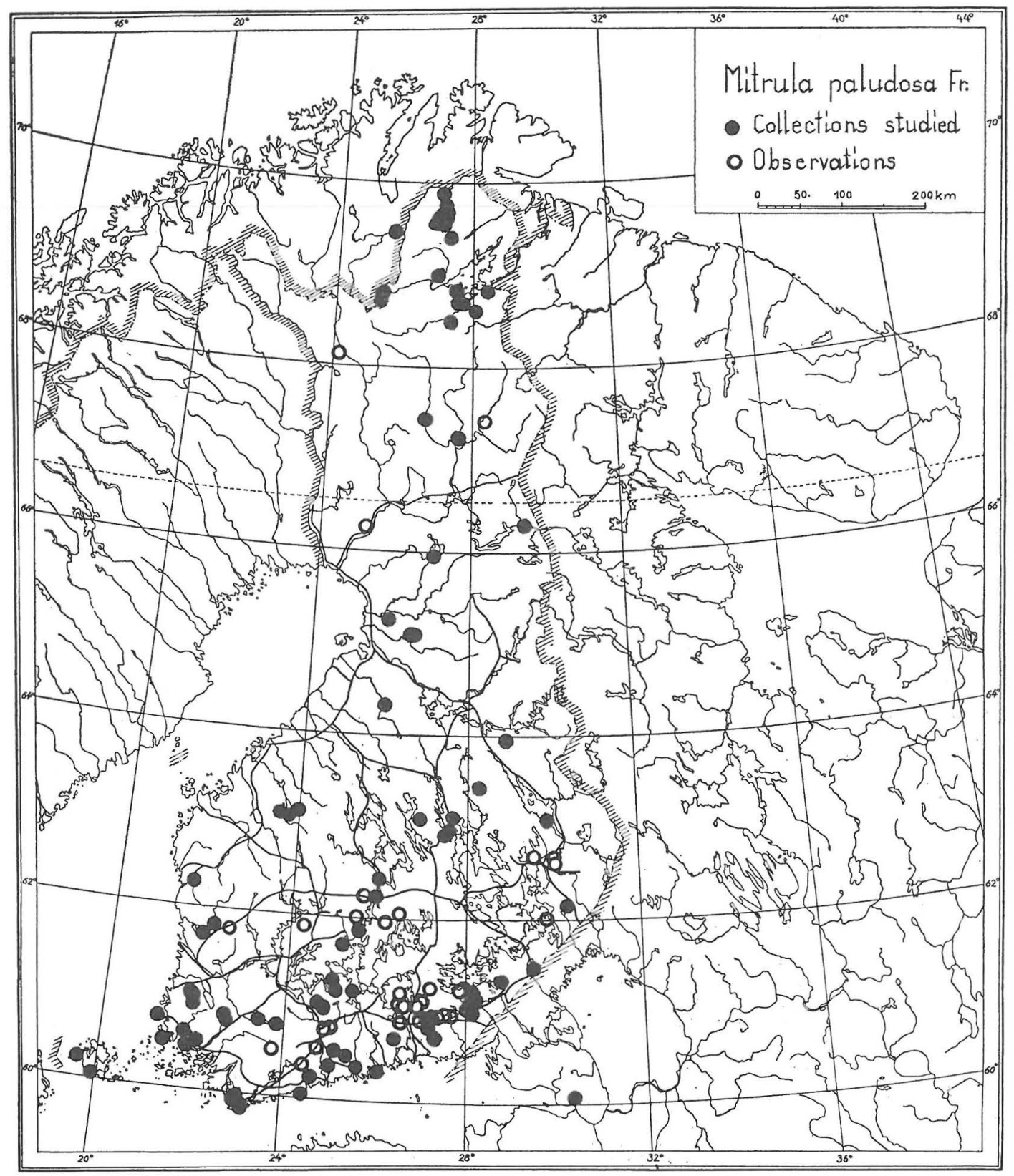

Fig. 1. The studied collections and observations of Mitrula paludosa Fr.

Såltin (TUR); O r i p ä ä Myllylähde 13.7. 1956 L. E. Kari (TUR), 30.6. 1968 Martti Kemilä (OULU); Pomarkku Uusikylä 19.6.1939 Matti Laurila (HPP).

Ta. A s ik k l a 15.6. 1863 J. P. Norrlin (H); J a nakka la Koljala Suurisuo 5. 7. 1968 Pertti Uotila $(\mathrm{H})$; J ok i o in e n 22.6.1910 S. Salmenlinna $(\mathrm{H})$; J äm s ä Jämsänniemi Myllyjärvi 26 . 7. 19.64 Raikko Ruotsalo (H); $\mathrm{Ku} \mathrm{h}$ mo in en Puukkoistenkoski 22 6. 1965 Yrjö Mäkinen (TUR); L a m m i Evo 24.6.1965 Harri T. Toppari (H),
Porraskoski 19.8.1952 Otto v. Schulmann (H); $\mathrm{T}$ a m mela Mustiala 30.7. 1866, 23. 7. 1869, 24. 7. 1869 P. A. Karsten (H) and 27.6.1867 A. L. Borenius (H); V a n a j a Isojärvi 8. 7. 1965 Harri T. Toppari (H).

Tb. L a u k a a Seppälä 14. 6. 1915 Anne-Marie Häyrén (H), Valkola 18.9.1949 E. J. Valovirta $(\mathrm{H})$

Kol. Parikka la Kasuri 21.6.1955 Otto v. Schulmann (HFR).

Ka. Sippola Enäjärvi 6. 7. 1948 Viljo Ku- 
jala (HFR), Kaipiainen 26. 6. 1949 Viljo Kujala 428 (HFR); Vehk a la h ti Pyhältö 19.6.1947 Lars Fagerström $(\mathrm{H})$.

Kb. P i e lis järvi Koli 24. 8. 1956 Viljo Kujala (HFR); R a u t a va a r a Suojärvi 8. 7. 1952 Albert Korhonen (H); Tohmajärvi Hernevaara 27.6.1966 Esteri Kankainen (TUR).

Sa. L a p p e e Korkeamäki 8. 6. 1906 Hans Buch (H), Vehkasalo 26.6. 1957 collector unknown $(\mathrm{H})$ and 20. 6. 1959 Kirsti Sandberg (H); Ruokol a hti Inkilänmäki 24.6.1967 Terho Poutanen (TUR); T a i pa ls a a r Halila 1. 7. 1966 Orvo Vitikainen $206(\mathrm{H})$.

Sb. K u o p i o Pitkälahti 30.6. 1949 Ritva. Ruotsalo (HFR), Särkilahti 9.6.1909 K. Linkola (TUR); Siilin järvi Kasurila 14.6.1912 Lauri Korhonen (HFR); T e rvo. Talluskylä, in 1938 Anu Malinen ( $\mathrm{H})$.

Oa. L a p väärtti Pyhävuori 1.7.1948 Artturi Railonsala (TUR) and 4.7.1957 G. Nordström $(\mathrm{H})$.

Om. L a p a järvi Savo 21. 7. 1904 A. L. Backman (HFR); Pulk kila Niskankylä 5.8. 1966 Tauno Ulvinen (OULU) ; V i mpeli Koskela 17.6. 1904 A. L. Backman (HFR), Pyhävuori 22. 7. 1903 A. L. Backman (HFR).

Ob. Haukipudas Martimo 10.7. 1966/ XXVI Martti Ohenoja (OULU); $\mathrm{K}$ i i m in k i Haara 25. 6. 1966/III Martti Ohenoja (OULU), Juuansydänmaa 25.6.1967/V Martti Ohenoja (OULU).

$K n$. S o t k a m o Lontta 29. 6. 1945 Jaakko Jalas $(\mathrm{H})$.

Ks. K u u s a mo Juuma 6.8. 1948 L. E. Kari (TUR).

Lkem. Pelk os e n n i emi Kairala 15. 6. 1937 Richard Frey (H); Sodankylä 24.8.1947 Viljo Kujala (HFR)

Li. I n a ri Kyrö, in about 1920 A. R. Ruoranen $(\mathrm{H}), 5 \mathrm{~km}$ west of Ivalo 15. 7. 1968 Yrjö Mäkinen (68-262) \& Marja-Leena Halme \& Leena Laitinen (TUR, KEVO), along Ivalo-Inari road south of Myösäjärvi 9.8.1968 Yrjö Mäkinen (TUR), $4 \mathrm{~km}$ south of Tolonen 20. 7. 1968 Yrjö Mäkinen \& Esteri Kankainen (TUR), Tsharmitunturit Laanaselkä 1. 8. 1968 Esteri Kankainen (TUR); Uts joki Jesnalvaara 3.9.1968 Paavo Kallio (KEVO).

\section{USSR}

Lim. K a n t a lahti in 1843 Fr. Nylander $(\mathrm{H})$. Lpets. Petsamo Alaköngäs 13.7.1932 E. Häyrén $(\mathrm{H})$.

Prov. Petropolitanae. Jukki prope Pargala 26. 5./ 7. 6. 1898 legit Tranzschel (S). (See Naumov 1964, p. 230$)$.

\section{CANADA}

Newfoundland-Labrador. E s k e r east shore of Menihek Lakes west of Esker, 53 5.2'n.lat., 66 ${ }^{\circ} 26^{\prime}$ w.long., elevation 1600 ft. 23. 7. 1967 Esteri Kankainen (TUR).

List of the observations of Tauno Ulvinen (marked with rings on the enclosed map, Fig. 1):

$A b$. B r o m a r v Hankoniemi 7. 8. 1955; Vih t i Nummela Kotokorpi 11.6. 1960.

N. Nurmijärvi Noppo Perkelsuo 16.6. 1958 .
St. K a n k a n pää Kuninkaanlähde 18.6. 19.57.

Ta. H a u järvi church village 16. 6. 1958 $\mathrm{J}$ a a l a church village Iso Ruhmasjärvi 30.7. 19:56, Retusjärvi 31.7. 19:57, «Ritti« 7. 7. 1963, Hartola 6. 7. 1963; Ku us a n koski Keltti 1C. 6. 19.59; Riih imäki 21.7.1956; Ruoves Jäminkipohja 30.6.1957; S o m e rniemi Mäyrämäki 13. 6. 1957.

Ka. S i p p ola Kaipiainen 19.6.1953, Pajari 29.6. 1953 .

$K b$. K i t e e Juurikka-aho along Kaarlola road 18. 7. 1957; Kontiolahti Kulho 15.7.1957, Paihola 14. 7. 1957; Li peri Vaivio 12. 7. 1957. Sa. Kangasniem i Paappala 3.7.1963; La p pee Myllylä 20.8.1953; Leivonmäki church village 1. 7. 1963; L u u mäki Somerharju 22. 6. 1953, between Somerharju and Taavetti in 1953, Uro 16. 8. 1953; $\mathrm{M}$ änty harju Partsimaa 8.7.1963; T a i pals a a ri Karhula 12. 8. 195.6, Leväinen 12.8.1956; Valk a l a Anttila 4.8.1956, Hevosoja 5.8.1956, Mankki 2. 7. 1953, Utti 8.7. 1957.

Ob. K i i m in k i Joutenojanpalo 19.6. 1963.

Lkem. S avukoski Martti in 1961 (cf. ULVINEN 1963, p. 54).

Observations of Lauri Teivainen in HFR (marked with rings on the enclosed map, Fig. 1):

Ta. Korpilahti Oittila, in 1946.

Tb. Jyväs kylä Vesanka, in 1945.

$O b$. Rovaniemi Pisavaara (two finds), in 1946-47.

Lkem. Kit tilä-En o n t e ki ö Pallas-Ounastunturi (three finds), in 1948-49.

All observations of Lauri Teivainen are from wet copse fen. We must, however, be critical with the observations in $O b$ and Lkem, because there is a possibility of confusing Mitrula paludosa and $M$. gracilis.

2. Mitrula gracitis Karst., Hedwigia 22, p. 17. 1883 .

Mitrula muscicola E. Henn., Öfvers. Kongl. Vet.Akad. Förhandl. 1885, p. 71, Tab. 8, Figs. 6-8. 1885.

Mitrula rehmii Bres., Fung. Trid. 2, p. 41, Tab. 147, Fig. 2. 1892.

Mitrula gracilis var. flavipes Peck, Ann. Rep. N. Y. State Mus. 49, p. 32. 1896.

Gymnomitrula gracilis Imai, Journ. Fac. Agric. Hokkaido Imp. Univ. 45, p. 175. 1941.

Gymnomitrula rehmii Favre, Ergebn. wiss. Unters. schweiz. Nationalparks 5:42, p. 383. 1960.

Typus: In Herb. Karsten, Mus. Bot. Univ. Helsingfors. Knäsä-guba 5. 8. 1961 P. A. Karsten.

Exsiccate: Fungi exs. Suec., No. 1784.

External morphology. Mitrula gracilis is a rather inconspicious species in so far as it does not grow in abundance. It differs from M. paludosa and Heyderia abietis chiefly in 


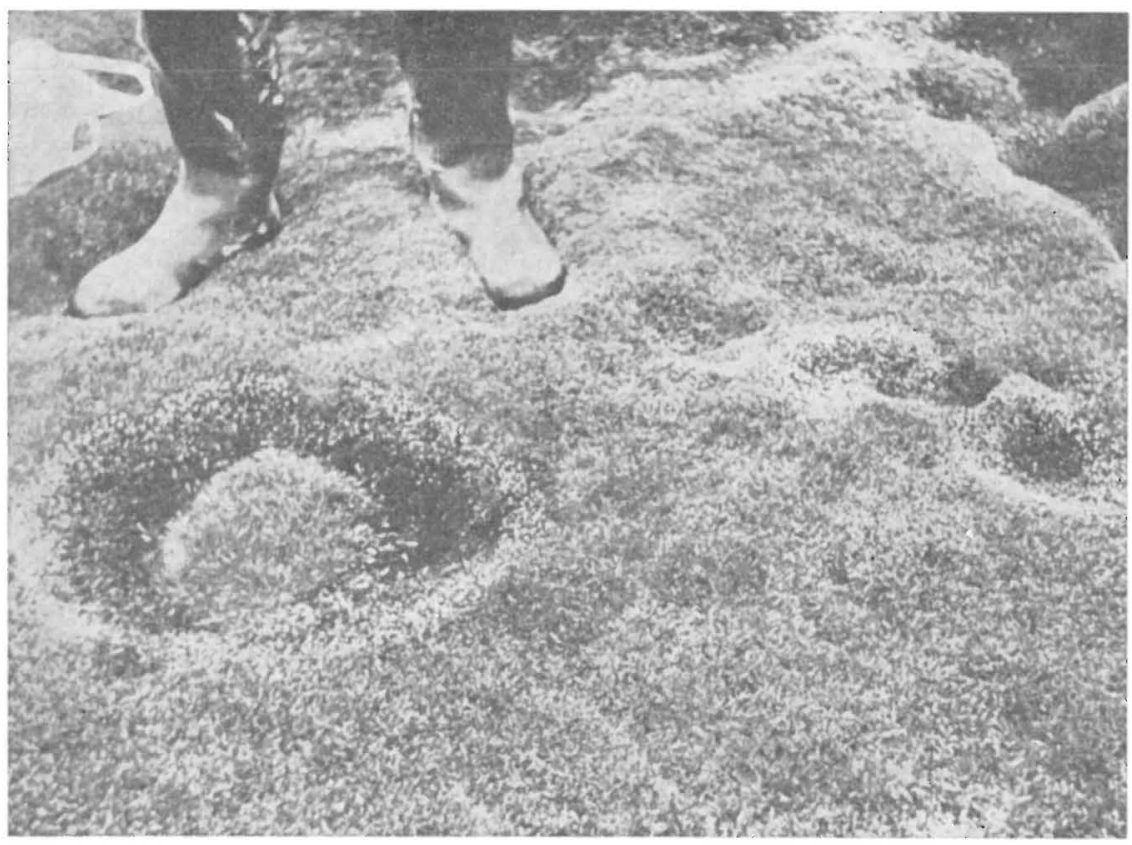

Fig. 2. A circular population of Mitrula gracilis Karst. on the Calliergon sarmentosum mat. Spitsbergen, Kongressdalen, in 1966.

colour, in size of asci and spores, and in habitat.

The height of the studied ascocarps varies from 0.7 to five centimetres. The stipe is yellowish or ochraceous in fresh material, but in some specimens it is whitish because of the presence of white, partly hyaline scales and hyaline hairs. The scales are poorly seen in dry material. The base of the stem is rugged, somewhat thickened, and divided into many fibres crossing the rhizoids of the host moss. The form of the ascigerous portion and its connexion with the stipe varies between that of Mitrula paludosa and Heyderia abietis. The head and stipe are, however, almost the same colour when fresh.

Two extreme morphological forms can be distinguished in Mitrula gracilis material. In some specimens the fertile, c a p it a t e, more or less folded head continues to the stipe without a distinct sterile zone. In very young ascocarps of this type, however, a free margin, filled with mucilaginous matter and hanging over the apex, can be seen (Tauno Ulvinen, by letter).

The specimens of the other type have a pil e a te, unfolded head with a sharp overhanging margin. The surface of the broad sterile area is somewhat reticulated. These kinds of specimens are as a rule smaller and paler, and the stipe is more scaly than in the former type. They have features, even when adult, similar to the juvenile stage of M. gracilis.

Though the extreme specimens among the studied material differ very conspicuously from each other it is not necessary to attach great importance to them as separate species, or even as variations, because mediator specimens exist in this material. For instance most specimens from Canada indicate an infraspecific series. Some of these are also from Lapland, although it is very difficult to distinguish this group. Most material from northern Fennoscandia is of the capitate form. Some specimens from the northernmost Fennoscandian research area and all material from Spitsbergen are of the extreme pileate form.

Particularly in dry material from Canada, but also in the pileate specimens rests of a veil between the stem and the head can be seen. When dried or preserved in alcohol the colours of $M$. gracilis, like $M$. p.aludosa become far darker, and the stipe and the head are no longer uniformly coloured the stipe being (lemon) yellow, and the head reddish brown. 
Anatomy. The anatomy does not vary like the external morphology of the species in question. The hyphae in the axis of the stipe are up to $8 \mu$ wide, in the periphery $4-5 \mu$ wide. The hairs are hyaline, one- and twocelled, up to $30 \mu$ long. The scales extend upward, and they turn dark blue with cotton blue.

The asci average $65-85 \times 6-7 \mu$ (measured in five specimens). The tips of the asci turn blue with iodine. The paraphyses are numerous and slightly thickened above. The spores are hyaline, somewhat punctate (best seen with oil immersion), often uniseptate, more or less straight, fusiform. The size of the spores in the following collections is: $\mathrm{Ra}$ nua 22.7. $19439.2 \times 2.4 \mu \quad(50$ measurements); Kuusamo 6. 8. $19489.8 \times 2.0 \mu(50$ meas.); Kiiminki 21. 7. $196611.2 \times 2.8 \mu$ (30 meas.); Utsjoki 14. 8. $196312.5 \times 2.7 \mu$ (30 meas.); Spitsbergen Kongressdalen 16. 8. $196611.1 \times 2.6 \mu$ (50 meas.) ; Cianada: Beam Lake 6. 8. $196311.6 \times 2.6 \mu$ (25 meas.), Attikamagen Lake 5. 8. $196711.7 \mu \times 2.6 \mu$ (30 meas.), Highfall Creek 2. 8. $196711.2 \times$ $2.5 \mu$ (25 meas.). The specimens from Ranua, Kuusamo and Kiiminki are of the capitate form, the specimens from Utsjoki and Spitsbergen of the pileate form.

Many different observations and opinions have been presented on Mitrula gracilis and the related species. The notes on the anatomical features do not vary greatly, but the morphology has caused much confusion.

Karsten (1883) considers this species to be between $M$. elegans and $M$. paludosa. DuRAND (1908) however, has combined the mentioned two species as one species $M$. phalloides. Massee (1897) says that $M$. rehmii in many points resembles $M$. muscicola - which subsequently is enclosed with $M$. gracilis but has a «somewhat longer stem and more uneven hymenium《 (p. 280). REHM (1896) assumes $M$. gracilis and $M$. rehmii to be variants of same species. Durand (1908) has studied the type of Karsten, and he writes that the American specimens agree well with the type. He has found that $« M$. gracilis agrees with $M$. muscicola and $M$. rehmii in habitat and differs from them pricipally in the smaller size and more even hymenium « (p. 404). Seaver (1911) observed the large variability of the ascocarps of $M$. gracilis.

The morphology and anatomy of our ma- terial correspond to those of $M$. rehmii of Bresadola (1892, p. 41). Herm \& Remy (1932, p. 68) widen $M$. rehmii and describe the «forme alpine FELDT (1942, p. 50) is M. gracilis, while the «forme sylvatique subalpine« - Bresadola's original type - should perhaps be different. According to HeIM \& REMY both forms have much larger asci and spores than the type described by Bresadola. The spores are also very irregular in form.

NANNFELd (1928) has studied herbarium material of M.rehmii, and he says that it is a good deal larger than $M$. gracilis. The author has seen a specimen of the exsiccate material of LundeLL \& NANNFELDT, and it corresponds well with the capitate type described above.

IMAI (1941) on the basis of DitTriah's (1898) and CoRNER's (1930) investigations separated $M$. gracilis and $M$. cucullata to his own genus Gymnomitrula instead of Heyderia, which according to ImaI is already occupied. Thus also M. gracilis should be gymnocarpic like $M$. pusilla. But the developmental phases of $M$. gracilis have not yet been clarified, and the possibility that $M$. gracilis might be angiocarpic is not excluded. That is why we for the present place the species in Mitrula. For instance rests of a veil in our specimens may resemble those seen in $M$. paludosa (Durand 1908, p. 389, NANNFELdT 1932, p. 317).

In 1949 FAVRe has united $M$. rehmii in M. gracilis and M. muscicola. In $1960 \mathrm{FAVRE}$ recorded Gymnomitrula rehmii as synonym of Gymnomitrula gracilis. Marns (1955, p. 871) has observed some variation in $M$. gracilis in America. He writes that «In some ascocarps the stipe gradually widens above, forming a sterile area on the lower portion of the head《. Lange (1957) assumes that $M$. gracilis is possibly confused with $M$. multiformis.

Skirgiello (1961) has studied material collected from Spitsbergen, and she reports those specimens to have an overhanging margin. EGKBlad (1963, p. 151), however, writes that Skirgiello's illustration «seems to indicate another plant«. In our opinion the material described by Skirgiello agrees entirely with our specimens from Spitsbergen, in other words with the pileate form described above. Similarly the finds from Jan Mayen (LARSEN 1924) may be of this type. 
BENEDIX (1962) and SvrčEk (1962) record from the Tatra Mitrula material the place of which in their opinion is uncertain as regards $M$. rehmii and $M$. gracilis. According to Benedix (p. 404) M. gracilis has a shorter stipe than $M$. rehmii. About his own Tatra material BENEDIX says that those specimens have no sharp overhanging margin, but they have the uneven head typical of $M$. rehmii. We assume that $M$. rehmii and $M$. gracilis sensu BENEDIX perhaps correspond in some degree to the variation described above. BENEDIX does not exclude the standpoint of ReHM (1896) who considers $M$. gracitis and M. rehmii variants of the same species. BenEDIX, however, placed $M$. rehmii together with $M$. paludosa and M.omphalostoma in the subgenus Physomitrula and $M$. gracilis together with $M$. abietis in the subgenus Heyderia.

Eakblad (1963) and Maas Geesteranus (1964) have studied the anatomy of the stipe of Mitrula species. MaAs Geesteranus (p. 89) says that «the very different structure of the stipe in itself is sufficient proof that Mitrula gracilis is not a Heyderia. I am not sure, however, as to its relation to Mitrula.« The anatomy of the stipe in our specimens nearly corresponds to that presented by ECKBLAD (1963) and Maas Geesteranus (1964) except that neither author has observed any hairs or scales on the stem. Ulvinen (by letter) has seen scales in his $M$. gracilis material from Enontekiö. Though the existence of such special structures brings $M$. gracilis in some way closer to Heyderia (sensu MaAs Geesteranus), it is not justifiable to place it in Heyderia. In our opinion it is thus reasonable to keep $M$. gracilis in Mitrula, but the study of the juvenile development is necessary.

Habitat. Mitrula gracilis grows on wet mossy places between hummocks in bogs. The studied specimens have been found on many different moss species. It is surprising that the extreme morphological forms presented above have no notable preference concerning to the mosses on which they live. Both forms are found on Aulacomnium palustre, Drepanocladus revolvens, and on Paludella squarrosa. In Lapland Paludella seems to be the most common host moss for the larger, capitate form. In addition it has been found connected with Bryum pseudotriquetrum, Calliergon stramineum, Campylium stella- tum, Helodium blandowii, H. lanatum, and with Philonotis tomentella. The gracile, pileate form in our collections is connected also with Calliergon sarmentosum, Oncophorus wahlenbergii, and with Tomentypnum nitens.

Very often brown dead patches on moss mats around $M$. gracilis populations have been found. The phenomen is most obvious when a bright green moss species (for instance Paludella squarrosa or Calliergon sarmentosum) forms a more or less pure growing unit, and when the fungus grows in abundance. The most regular growing units we have seen in Spitsbergen (Fig. 3) where such brown rings are very conspicuous in some bogs (Kankainen \& KarLSTRÖм \& HeIKkIL $\ddot{A}$ 1967). The fungus widens its growth area centrifugally while in the centre of the dead ring new, vigorous, bright green moss begins its growth.

In the literature $M$. gracilis is recorded growing on Aulacomnium palustre, Bryum pseudotriquetrum, Calliergon sarmentosum, C. stramineum, Dicranum majus (!), Drepanocladus badius, Dr. exannulatus, Helodium lanatum, Hylocomium splendens, Paludella squarrosa, Philonotis fontana, Ph. tomentella, Rhacomitrium canescens, $R$ h. fasciculare, Tomentypnum nitens, and on Webera nutans (Henning 1885 concerning $M$. muscicola, Bresadola 1892 concerning M. rehmii, Durand 1908, Heim \& Remy 1932 concerning M.rehmii, NANnfELdT 1942, Mains 1955, BENEDIX 1962 concerning M. rehmii and M. gracilis, EGKBlad 1963, Kallio \& KANKAINEN 1964).

Some authors have reported that the moss underneath the fungus is dead (Karsten 1883, Elgkblad 1963, Kallio \& Kankainen 1964). Some authors assume that the fungus is a parasite (BREsadola 1892, Durand 1908, Imai 1941, Mains 1955). Nannfeldt (1942) had seen only healthy moss below the fungus. EGKBLAD (1963) writes that he and Mr. S. Sivertsen have observed almost circular brown patches on the moss mats. Ulvinen (by letter) has found $M$. gracilis (the pileate form from Enontekiö) killing Aulacomnium palustre.

EGKblad (1963, p. 152) says that «If such (infraspecific) taxa exist they will probably exhibit some specialization as regards the substratum, in the way that different taxa occur on different mosses. This does not mean 


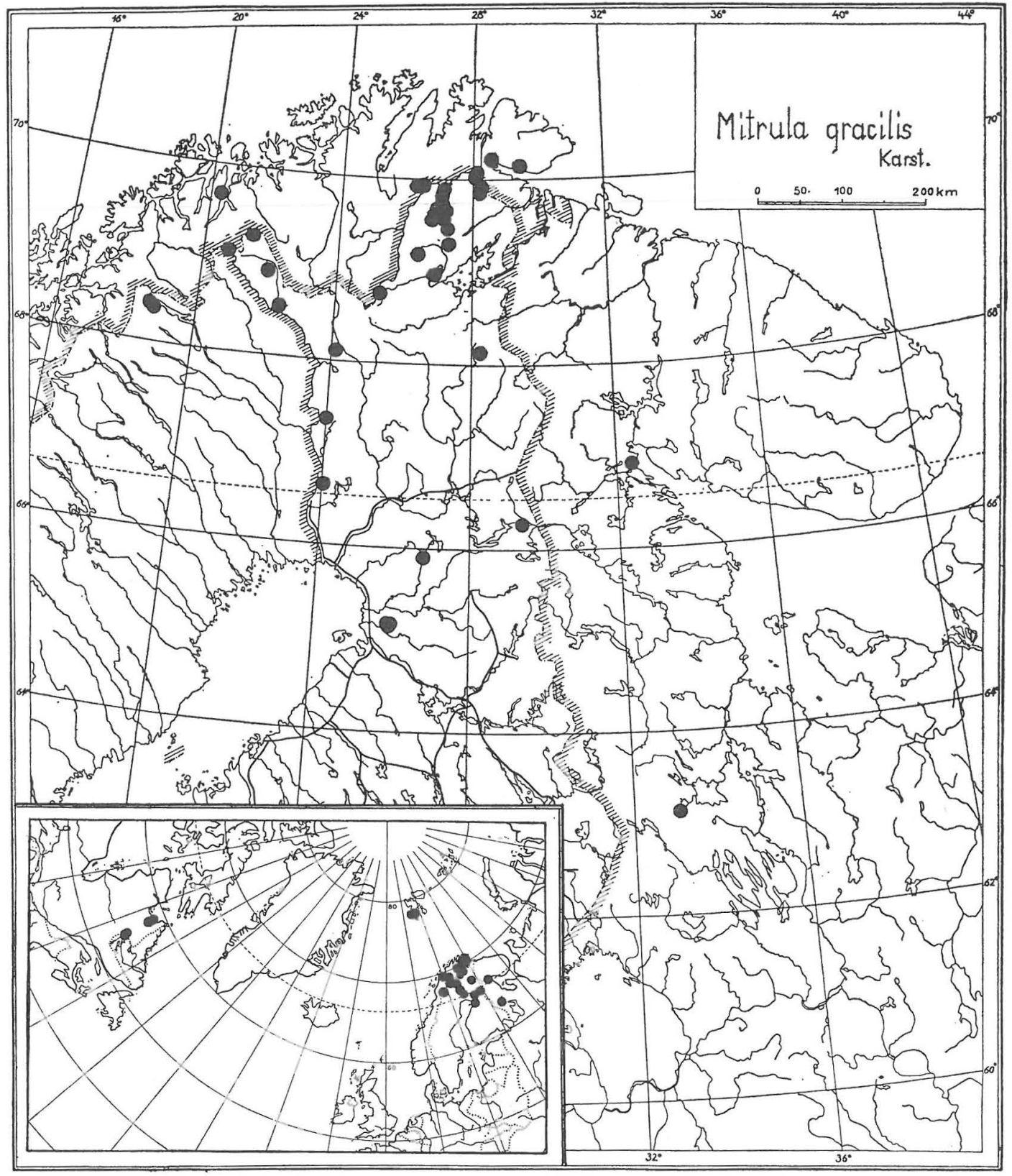

Fig. 3. The studied collections of Mitrula gracilis Karst.

that we should expect a usual host - parasite relation«. Further on EGKBlad reports he has not seen any fungal hyphae within the cells of the moss. Neither have we observed fungal hyphae penetrating the moss cells. We are of the opinion that the fungus gets nutrients diffusioned from the exuding liquid of the moss. The toxic effect of the fungus is an axiom but it can be a secondary handicap effect which does not necessarily have to do with the nutrition of the fungus (cf., too, ECKBLAD 1963, p. 152). On the other hand the toxic effect may be also a primary effect increasing the permeability of the cell membranes in the host moss.

As seen above there is very large variation which does not seem to depend noteworthy on the moss substrate. The variation does not 
obviously correspond to the «biologic variation « of Mitrula abietis (VELENOVsky 1934, ULVINEN 1966) because the nutrition is different in $M$. gracilis and M. abietis. It is necessary to know more about the nutrition in $M$. gracitis and about the influence of e.g. the temperature on the morphogenesis of this species before the problem of variation is solved.

Phenology. Mitrula gracilis is a species between M. paludosa and Heyderia abietis as regards the period of growth, for it is a species of summer and autumn. The capitate specimens in the studied material seem to be earlier than the pileate types. The former is found to occur from the middle of July to August 21, the latter from August 6 to September 12. The specimens from Canada are collected between July 31 and August 6 . The climate fluctuates very much from year to year. For instance the summer and autumn in Finland in 1967 was warmer than average. In 1968 the summer was exceptional cold in Lapland.

In Fennoscandia the peak of occurrence of M. gracitis is clearly in August, as seen in the following table, which presents the collections reported by KANKAINEN in this article (abbrev. K), by Kallio \& Kankainen 1964, 1966 (K \& K), Nannfeldt 1942 (N) and EGKblad 1963 (E).

\begin{tabular}{crcc}
\multicolumn{4}{c}{ Number of collections } \\
& $\mathrm{K}$ & $\mathrm{K} \& \mathrm{~K}$ & $\mathrm{~N}$ \\
During June & 1 & - & - \\
《 July & 2 & 4 & 2 \\
« August & 16 & 26 & 8 \\
« September & 6 & - & 1
\end{tabular}

E

Also the notes of the other authors nearly conform to that reported above as regards the period of growth in M. gracilis (KARSTEN 1883, Imai 1941, Mains 1955). Durand's note $(1908$, p. 403) «March(?) - September is really doubtful. In the Alps and in the Tatra the species is found in September (HeIm \& Remy 1932 concerning M. rehmii, BENEDIX 1962).

Distribution. (Fig. 3) The distribution of the different forms of $M$. gracilis is already treated above. The capitate form is found to occur from $63^{\circ} 20^{\prime}$ to $70^{\circ}$ n.lat. and the pileate form from $68^{\circ}$ to $78^{\circ}$ n.lat. The collections in Canada are made in the latitudes of $54^{\circ}$ and $58^{\circ}$ n.lat.

Mitrula gracilis is a subarctic-arctic-alpine fungus. It is recorded from the Kola Peninsula (Karsten 1883), from northern Fennoscandia (Henning 1885: M. muscicola, RoSTRUP 1904, NANNFEldt 1928, 1942, ImaI 1940, Eakblad 1963, Kallio \& Kankainen 1964, 1966), from Spitsbergen (Skirgiello 1961, Kankainen \& Karlström \& Heikmil Ä 1967), Jan Mayen (LARSEN 1924), Iceland (LARSEn 1932), Greenland (Rostrup 1891, 1894, Lange 1957), from North America (Durand 1908, Marns 1955), Japan (ImaI 1941), from the Alps (BRESADOLA 1892: M. rehmii, HeIM \& Remy 1932: M. rehmii, Favre 1949, 1955, 1960, Skirgiello 1961, EIsfelder 1962), and from the Tatra (BENEDIX 1962, SVRČEK 1962).

List of the specimens studied (marked with dots on the map, Fig. 3, together with the collections reported by KALLIO \& KANKAINEN 1964, 1966):

\section{FINLAND}

$O b$. K i im inki rich fen between old Kuusamo road and Jolosjoki river (on Aulacomnium palustre, Bryum pseudotriquetrum, Drepanocladus revolvens etc.) 21.7.1966 Tauno Ulvinen (OULU), and 2.8.1966 Tauno Ulvinen (OULU, TUR), (on Bryum pseudotriquetrum) 5.9.1968 M. Ohenoja \& T. Ulvinen (OULU), southwest of the central swamp of Murtoinsaaret 8.9.1968/ XXXV Martti Ohenoja (OULU); R a n u a Isopalo (on Helodium blandowii, Paludella squarrosa) 22. 7. 1943 A. V. Auer (TUR).

Ks. K u u s m o Juuma (on Paludella squarrosa) 22. 8. 1923 Harry Warén, det. Matti Laurila 1938: Mitrula gracilis Karst. = M. muscicola E. Henning (TUR).

Le. E n o n t e k i ö Hirvasvuopio (on Helodium blandowii) 12. 8.1961 H. Roivainen $(\mathrm{H})$ and (on Paludella squarrosa) 10. 8.1961 Laila \& H. Roivainen (H), Markkina (on Aulacomnium palustre) 12. 9. 1967 and 16.9. 1967 Tauno Ulvinen (OULU), Toskaljärvi (on Calliergon sarmentosum, Drepanocladus exannulatus) Aug., 1967 A. J. Huuskonen (TUR), Kilpisjärvi Saana (on Bryum) 18. 9. 1968 Tauno Ulvinen (OULU).

Li. U ts joki Pulmanki Ruossavaara (on Calliergon stramineum) 14.8.1963 Yrjö Mäkinen (TUR), east side of the lake Kevujärvi (Kevojärvi) (on Paludella squarrosa) 21.8.1965 P. Kallio \& E. Kankainen \& O. Skifte (TROMS), southwest slope of Kenishpakte (Kenespahta) cliff 18. 8. 1965 Ola Skifte (TROMS).

\section{NORWAY}

Troms. Lyngseid e t Råttenvikfjellet (on Helodium lanatum, Paludella squarrosa) 25.7. 1968 Reino Alava \& Kalevi Alho (TUR). 
Finnmark. Polmak palsa bog west of Varangerbotn (on Paludella squarrosa, Drepanocladus) 12. 8. 1968 Esteri Kankainen (T'UR) and 20.8. 1968 Anja Niskanen (TUR, KEVO).

Svalbard. Vestspitsbergen Isfjorden southwest of Festningen 14.8.1966 Paavo Kallio \& Esteri Kankainen (TUR), near the Isfjord Radio Station (on Drepanocladus revolvens, Oncophorus wahlenbergii) 13.8.1966 Heli Heikkilä (TUR, KEVO) and (on Calliergon sarmentosum) 17. 8. 1966 Paavo Kallio (TUR), Kongressdalen (on Calliergon sarmentosum) 16.8.1966 Esteri Kankainen (TUR, KEVO), southwest side of Linnévatnet (on Drepanocladus) 12.8.1966 Heli Heikkilä (TUR), west side of Linnévatnet (on Calliergon sarmentosum) 13. 8. 1966 Heli Heikkilä (TUR), Vardåsen (on Tomentypnum nitens) 18. 8. 1966 Esteri Kankainen (TUR).

\section{SWEDEN}

Torne Lappmark. J u k k a s jä rvi Abisko (on Paludella, Drepanocladus?) 5. 6. 1943 Rolf Santesson (S), Kopparåsen (on Paludella, Drepanocladus) 6.8.1943 Rolf Santesson (S).

USSR

Kpoc. Pa atene (on Philonotis tomentella) 15. 7. 1869 J. Sahlberg (TUR).

\section{GANADA}

Newfoundland-Labrador. $\quad \mathrm{S} \mathrm{c}$ h e f f e rville a rea, southeast of Mike Lake $54^{\circ} 40^{\prime}$ n.lat. $66^{\circ} 37^{\prime}$ w.long., elevation 1650 ft. 4. 8. 1967 Esteri Kankainen (TUR), southwest shore of Attikamagen Lake 54 $54^{\prime}$ n.lat., 66 37' w.long. (on Aulacomnium palustre) 5.8.1967 Esteri Kankainen (TUR), northwest shore of Petitsikapau Lake (on Paludella squarrosa) 6.8.1967 Paavo Kallio (TUR, KEVO), north shore of Beam Lake $54^{\circ} 45^{\prime}$ n.lat., $66^{\circ} 49^{\prime}$ w.long., elevation $1700 \mathrm{ft}$. 6. 8.1963 Paavo Kallio (TUR).

Quebec-Labrador. Fort $\mathrm{Chimo}$ a rea, Highfall Creek, north of the falls $58^{\circ} 01^{\prime}$ n.lat., $68^{\circ} 29^{\prime}$ w.long. (on Drepanocladus revolvens) 2.8.1967 Esteri Kankainen (TUR), Old Fort Chimo $58^{\circ} 09$, n.lat., $68^{\circ} 18^{\prime}$ w.long. (on Paludella squarrosa) 31.7.1967 Esteri Kankainen (TUR).

He y de ria Weinmann, Syll. Pl. nov. 2, p. 108. 1828.

3. Heyderia abietis (Fr.) Weinmann, Syll. Pl. nov. 2, p. 108. 1826. - Link, Handb. Erkenn. Gewächse 3, p. 311. 1833.

In 1966, Ulvinen wrote about this species and renewed FrIes' (1828) «Mitrula Heyderia Abietis« and M. Heyderia pusilla«. We only list the unpublished notes. For the information as regards the nomenclature of this genus we thank Dr. R. A. Maas Geesteranus and Phil. lic. Tauno Ulvinen.

Heyderia abietis is a species of the autumn. It can be found even during November. It is recorded to occur except in the northern hemisphere also in Australia (ImaI 1941).

List of the specimens studied:

Heyderia abietis var. abietis

\section{FINLAND}

St. Lap pi Lapinkylä 20.10.1957 Holger Såltin (TUR), Simasalo 8.11. 1954 Holger Såltin (TUR).

Ta. J ok i o in e n Minkiö Nummela (fqq) 22. 10. 1967 Esteri Kankainen (TUR); Y lö järvi Mäkkylä 15.9.1968 Esteri Kankainen (TUR),

Teivaala 15, 9.1968 Yrjö Mäkinen (TUR).

Tb. Toivakka Huikko Riihimäki (also on pineneedles) 19.9.1968 Esteri Kankainen (TUR).

Sa. T a i p a ls a a ri Karhunpää 19.9. 1965 Orvo Vitikainen (TUR).

Ob. Ki iminki Kalkkialue 5.9.1968 Tauno Ulvinen (OULU).

\section{CANADA}

Newfoundland-Labrador. S $\mathrm{c}$ he f ferville a rea, southeast of Mike Lake (on the needles of Picea mariana and/or P. glauca) 54 $40^{\prime}$ n.lat., $66^{\circ} 37^{\prime}$ w.long., elevation $1650 \mathrm{ft}$. 4.8.1967 Esteri Kankainen (TUR).

\section{Heyderia abietis var. pusilla (Fr.) Ulv.}

\section{FINLAND}

St. K o k e mäki Kuivasaari 28. 9.1967 Aira

\& Kalevi Pohjola (TUR).

Ta. Ta m m e la Saloisjärvi 15. 10.1967 Esteri Kankainen (TUR).

$O b$. K i i m in k i Juuansydänmaa (also on spruce needles) 28. 9. 1968/XII Martti Ohenoja (OULU); Muhos Muhosperä 14.9.1968/XV and 14. 9. 1968/XLII Martti Ohenoja (OULU).

Le. Enontekiö $12 \mathrm{~km}$ northeast of Palojoensuu 12.9.1967 Tauno Ulvinen (OULU). This is the northernmost collection and it is made in the area where the spruce is completely lacking.

As seen above there is hardly a basis for the separation of different taxa. The cultivation of the species in different circumstances is needed.

\section{SUMMARY}

Mitrula paludosa Fr. is a species of spring and early summer. It is common in Finland up to the birch forest limit.

Mitrula gracilis Karst. is a subarcticarctic-alpine species. Its external morphology varies very much. Except the extreme capitate and pileate forms also infraspecific forms exist. The basis of the variation is not yet solved.

Heyderia abietis (Fr.) Weinm. grows on pine and spruce needles, but the separation of var. abietis and var. pusilla is not fully founded. The species is found in Finland up to the limits of the pine and spruce forest. 


\section{REFERENGES}

Benedix, E. H., 1962: Neues über die Geoglossaceen: Coelotiella, Mitrula. - Kulturpfl. Beih. 3, 389-410.

Bresadola, Ав. J., 1892: Fungi tridentini novi, vel nondum delineati, descripti, et iconibus illustrati II. - 46 pp., 150 tab. Tridenti.

Cooke, M. G., 1871: Handbook of British fungi II, 489-981. London.

Corner, E.J.H., 1930: Studies in the morphology of Discomycetes III The Clavuleae. Trans. Brit. Myc. Soc. 15, 107-120.

Ditrrich, G., 1898: Zur Entwickelungsgeschichte der Helvellineen. - Cohn's Beiträge Biol. Pfl. 8, 17-52.

Durand, E. J., 1908: The Geoglossaceae of North America. - Ann. Myc. 6, 387-477.

EGKBlaD, F.-E., 1963: Contributions to the Geoglossaceae of Norway. - Nytt Mag. Bot. 10, $137-158$.

Eisfelder, I., 1962: Höhere Pilze aus dem Pitztal (Tirol). - Ber. Bayer. Bot. Ges. 35, 2838.

Favre, J., 1949: A propos d'un Mitrula arcticoalpin (Mitrula gracilis Karst. = M. muscicola E. Henn. = M. Rehmi Bres.). - Schw. Zeitschr. Pilzk. 1949, 143-147.

- 1955: Les champignons supérieurs de la zone alpine du Parc National suisse. - Ergebn. wiss. Unters. schweiz. Nationalparks 5 (Neue Folge): 33, 1-212.

- 1960: Cataloque descriptif des champignons supérieurs de la zone subalpine du Parc National suisse. — Ibid. 6: 42, 323610.

Fries, E., 1821: Systema mycologicum I. - 520 pp. Lundae.

Heim, R. \& L. Remy, 1932: Especes rares ou nouvelles de Discomycètes des Alpes Briançonnaises. - Soc. Myc. France 48, 53-75.

Henning, E., 1885: Bidrag till svampfloran i Norges sydligare fjelltrakter. - Öfvers. Kong1. Vet.Akad. Förhandl. 5, 49-76.

IMAI, S., 1940: The Geoglossaceae of Norway. Ann. Myc. 38, 268-278.

- 1941: Geoglossaceae Japoniae. - Journ. Fac. Agric. Hokkaido Imp. Univ. 45, $155-$ 264.

- 1956: Contributiones ad studia monographica Geoglossacearum. III. - Sci. Reports Yokohama Nat. Univ. II: 5, 1-8.

Kallio, P. \& E. Kankainen, 1964: Notes on the macromycetes of Finnish Lapland and adjacent Finnmark. - Ann. Univ. Turku A II: 32 (Rep. Kevo Subarctic Sta. 1), $178-235$.

- 1966: Additions to the mycoflora of northenrmost Finnish Lapland. - Ibid. A II: 36 (Rep. Kevo Subarctic Sta. 3), 177-210.

Kankainen, E. \& P. Karlström \& H. Heikkilä, 1967: Kevolaisten retki Huippuvuorille v. 1966. - Luonnon Tutkija 71, 118-123.

Karsten, P. A., 1871: Mycologia Fennica 1. Pars prima Discomycetes. - Bidr. Känned. Finl. Natur och Folk 19, 1-264.

- 1883: Fragmenta mycologica. - Hedwigia $22,17-18$
- 1885: Revisio monographica atque synopsis. Ascomycetum in Fennia hucusque detectorum. - Acta Soc. F. Fl. Fennica II: 6, $1-174$.

LANGe, M., 1957: Macromycetes 3. - Medd. Grønland 148: 2, 1-125.

Larsen, P., 19.24: Fungi, in J. Gandrup: A botanical trip to Jan Mayen. - Dansk Bot. Ark. $4,23-24$.

Lloyd, C. G., 1916: The Geoglossaceae. - Mycol. Writings $5,1-24$.

Lundell, S. \& J. A. Nannfeldt, 1934-59: Fungi exsiccati suecici, praesertim upsalienses. Uppsala.

Maas Geesteranus, R. A., 1964: On some whitespored Geoglossaceae. - Persoonia 2, $81-96$.

MaINS, E. B., 1955: North American hyalinespored species of the Geoglosseae. - Mycol. $47,846-877$.

Massee, G., 1897: A monograph of the Geoglosseae. - Ann. Bot. 11, 225-306.

Nannfeldt, J. A., 1928: Contributions to the mycoflora of Sweden. 1. Discomycetes from Torne Lappmark. - Sv. Bot. Tidskr. 22, $115-139$

- 1932: Studien über die Morphologie und Systematik der nicht-lichenisierten inoperculaten Discomyceten. - N. Acta Reg. Soc. Sci Upsal. IV 8: 2, $1-368$.

- 1942: The Geoglossaceae of Sweden. Ark. Bot. 30 A: 4, 1-67.

Naumov, H. A., 1964: Flora gribov Leningradskoi oblasti II Diskomitseti. - 258 pp. MoskvaLeningrad.

Persoon, C. H., 1801: Synopsis methodica fungorum. - $708 \mathrm{pD}$. Göttingen.

Remm, H., 1896: Die Pilze Deutschlands, Oesterreichs und der Schweiz 3. - 1275 pp. Leipzig.

Rostrup, E., 1904: Norske Ascomyceter. - Vid. Selsk. Skrift. 1. Math.-naturv. Kl. 1904, 4, $1-44$.

Saccardo, P. A., 1889: Sylloge fungorum 8. Patavii.

Seaver, F. J., 1911: Studies in Colorado fungi I. Discomycetes. - Mycol. 3, 57-66.

Skirgiello, A., 1961: De quelques champignons supérieurs recoltes par M. Kuc au Spitsberg en 1958. - Bull. Res. Counc. Israel 10D, $287-293$.

SvrčEk, M., 1962: Diskomycety z Nizkých Tater, nalezené během posjezdové exkurze II. SEM. 1960. — Čes. Mykol. 16, 87-114.

Ulvinen, T., 1963: Beobachtungen über die Pilze von Savukoski, Nordfinnland. - Aquilo 1, $53-58$

- 1966: Úber die auf Koniferennadeln lebenden Arten der Gattung Mitrula s. lat. (Ascomycetes, Geoglossaceae). - Ann. Bot. Fenn. $3,433-438$.

Weinmann, J. A., 1828: Enumeratio fungorum in agro Pawlowskiensi praecipue crescentium. - Syll. Pl. nov. 2, 82-118.

Velenovsky, J., 1934: Monographia Discomycetum Bohemiae 1-2. - 436 pp, 31 tab. Pragae. 